Petra Stepišek, OŠ Šempeter $v$ Savinjski dolini

\title{
VLOGA SAMOSPOŠTOVANJA PRI RAZVIJANJU IZOBRAŽEVALNE POTI
}

\section{POVZETEK}

Avtorica v članku teoretično opredeljuje in išce povezavo med osebnimi vzgibi na ravni samospoštovanja pri razvijanju izobraževalne poti posameznika. Izobraževanje povzroči rekonstrukcijo posameznikove identitete, zaradi česar je pričakovati, da je tudi dosežena stopnja izobrazbe eden izmed dejavnikov, ki vplivajo na posameznikovo samospoštovanje in obratno. Prikazuje različne motive za razvoj izobraževalne poti odraslih. Le-ti so različni: zajemajo spodbude, želje, interese in potrebe. Ugotavlja, da so povezani z motivacijo, predstavo o sebi, svojih socialnih vlogah in z družbenoekonomskim položajem človeka. V članku so prikazani tako motivi za razvoj izobraževalne poti kot tudi vzroki za njeno prekinitev, ki se med posamezniki z različnimi stopnjami izobrazbe močno razlikujejo. Avtorica ugotavlja, da se razlike v samospoštovanju večajo glede na razpon med stopnjami izobrazbe. $Z$ nenehnim izobraževanjem in učenjem pridobiva posameznikovo samospoštovanje nove razsežnosti - višjo stopnjo izobrazbe kot je dosegel, širše dimenzije v zaznavanju sebe ima.

Ključne besede: samospoštovanje, izobraževalna pot, motivi, predstava o sebi

Zdi se, kot da stojimo pred ključno točko v razvoju izobraževanja. Vse večji pomen ima samouresničujoče učenje, $v$ katerem celo

Koncept kariernega razvoja se umika graditvi življenjske izobraževalne poti. odrasli postanemo navdušeni učenci, Kmalu ne bomo več govorili o graditvi kariere, temveč o graditvi življenjske izobraževalne poti. Hitrost in nepredvidljivost sprememb zahtevata tudi drugačen pogled na posameznikovo izobraževalno pot. $\mathrm{Ni}$ več nikakršne gotovosti, so le številne priložnosti. In ena največjih je neprestano spoznavanje, kako se učiti hitreje in lažje ter kako pridobljeno znanje uporabiti. Preživljamo revolucijo, ki spreminja način življenja, medsebojno komunikacijo in razmišljanje. Vsak bi moral vedeti, kdo je in kaj želi. Kot pravi Donald Super (v Brečko, 2000), vsak človek povsem spontano in povsem naravno teži $\mathrm{k}$ rasti. Zato se je pomembno zavedati svojih potencialov in biti človek $\mathrm{z}$ visokim samospoštovanjem. C̆lovek, v katerem je prisotna želja po odkrivanju novega in spreminjanju danega, ki ima voljo in moê za iskanje. In kaj je tisto $v$ naši naravi, kar nas žene, da iz znanega vedno silimo $v$ novo, neznano? Ne živimo zato, da bi preživeli, temveč je naše eksistencialno bistvo, da se želimo uresničevati. Uresničevati tudi z izobraževanjem. Glede na to, da je akademska samopodoba eden izmed pomembnih vidikov celotne samopodobe, bom v prispevku poskušala pojasniti vlogo samospoštovanja $v$ procesu izobraževalne poti posameznika. 
Izobraževalni proces se iz formalnih institucij seli v človekov intimni svet in odziva na najosebnejš̉e vzgibe. V članku skušam poiskati povezavo med osebnimi vzgibi na ravni samospoštovanja in graditvijo izobraževalne poti posameznika. Seveda pa ne gre prezreti teorije vseživljenjskega izobraževanja, ki ji namenjam uvodni del. Opredeljujem tudi pojem izobraževalne poti posameznika in dejavnike, ki pojem sooblikujejo. V nadaljevanju skušam teoretično opredeliti in povezati vlogo samospoštovanja pri razvijanju izobraževalne poti posameznika. Glede na to, da samospoštovanje ni enotna kategorija, temveč multidimenzionalen konstrukt, posameznik zavzame stališče o sebi na podlagi tega, kako uspešen je pri posameznih, ožje opredeljenih področjih delovanja (fizično, verbalno, intelektualno, socialno, čustveno ...). Zanimivo bo izvedeti, kakšno vlogo ima samospoštovanje pri razvijanju izobraževalne poti posameznika.

Ob predpostavki, da izobraževanje povzroči rekonstrukcijo posameznikove identitete, lahhko predpostavljamo, da je tudi dosežena stopnja izobrazbe eden izmed dejavnikov, ki vplivajo na posameznikovo samospoštovanje in obratno. Raziskujem tako vzroke za prekinitev izobraževalne poti posameznika kot tudi vzroke za nadaljevanje izobraževalne poti.

\section{TEORIJA VSEŽIVLJENJSKEGA IZOBRAŽEVANJA IN IZOBRAŽEVALNA KARIERA}

Teorija vseživljenjskega izobraževanja temelji na spoznanju, da odraslost ni podaljšano obdobje predvidljivih in konstantnih dogodkov. Prav prilagodljivost je namreč tista smernica, ki usmerja delovanje tako posameznikov kot tudi družbe in vseh njenih podsistemov.

Tudi v Sloveniji bomo v prihodnje verjetno prišli do spoznanja, da vlaganja $v$ izobraževanje in odgovornosti za učenje ni mogoče prepustiti pobudi posameznikov ali podjetij. Razvite države že uveljavljajo t. i. individualne izobraževalne račune kot in-

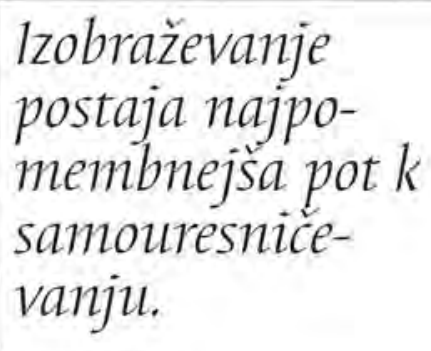
strumente za povečevanje izobrazbenega kapitala.

Cross (1981) v modelu CAL (Characteristics of Adults as Learners) povzema bistvene ugotovitve Knowlesa, Rogersa in ostalih teoretikov ter navaja bistvena načela, na katerih bi moralo temeljiti izobraževanje posameznikov $v$ učeči se družbi. Temeljilo naj bi na izkušnjah sodelujočih, prilagodilo naj bi se starostnim omejitvam sodelujočih, vsak naj bi napredoval $v$ svojem osebnem tempu ob širokem spektru možnosti za učenje tako v

Potreb vseživljenjskega izobraževanja smo se začeli zavedati, ko star, formalen sistem šolanja ni več zadoščal za potrebe nove družbe. Model družbe 21. stoletja namreč zahteva, da postanejo posamezniki samodejavni, samoučeči, samomotivirani, samozavestni upravljalci lastnega dela in kreativni gospodarji lastne prihodnosti. Kot pravi Peter Drucker, $v$ naslednjih dvajsetih letih starejša generacija ne bo imela tradicionalnega delovnega časa niti ne bo opravljala istega dela kot sedaj; glavna vrednota prihodnjih generacij bo znanje, zato bodo intelektualci $\mathrm{v}$ njej prevladujoči vir. Vsak posameznik si mora sam pridobiti znanje, saj se znanja ne da podedovati. Vsak začne s stopnje popolnega neznanja, znanje pa si pridobiva z učenjem. Drucker tako kot poglavitne značilnosti prihodnjih generacij navaja stanje brez meja - saj znanje potuje učinkoviteje kot denar -, mobilnost, splošno dostopnost formalne izobrazbe za vse, enake možnosti za uspeh in za neuspeh - vsak lahko znanje pridobi, a žal ga ne znajo vsi izkoristiti. (Drucker, 2001) Edwards (1979) navaja tri vrste učeče se družbe: učeča se družba kot izobraževalna družba (educated society), izobraževalni trg (learning market), omrežje za učenje (learning network). Vse tri koncepte lahko pojmujemo kot temeljne vidike učeče se družbe. 
dostopnosti kot sami organizaciji učnega okolja. (Cross, 1981) O učnem okolju razmišlja tudi Knowles, ko poudari vlogo učnega okolja pri učenju odraslih. To mora biti spodbudno, da se odrasli $\vee$ njem dobro počutijo in imajo občutek, da jih okolica sprejema, spoštuje in podpira ter da si svoje misli upajo izraziti brez strahu. Tudi učiteljev odnos do odraslih vpliva na njihovo uspešnost. Učitelj naj bi učence skušal osebno spoznati in jim pokazati, da ceni njihov prispevek v učnem procesu. (Knowles, 1980) Samo na takšen način bi lahko sledili cilju informacijske družbe, v kateri se povečujejo pomen individualnosti, posameznikova ustvarjalnost in inovativnost. Šele izobraževanje odraslih je namreč tisto, ki ponuja in daje možnosti za individualizacijo. Ravno zaradi tega v nadaljevanju namenjam več prostora razvoju izobraževalne poti posameznika.

\section{RAZVOJ IZOBRAŽEVALNE POTI POSAMEZNIKA}

$\mathrm{Na}$ vsakem koraku se nam ponujajo številne možnosti, da se kaj naučimo. Od vsakega posameznika, njegovih motivov, potreb, interesov in vrednot pa je odvisno, ali bo izbral

Število učnih okolij je vsak dan večje. možnosti, ki mu jih ponujajo številna učna okolja. Kot pravi A. Krajnc, smo tradicionalno poznali le šolo kot učno okolje, danes pa govorimo o številnih učnih okoljih. Človek je izpostavljen različnim učnim okoljem, saj se ljudje izobražujejo v različnih situacijah vsakdanjega življenja. Brez te raznolikosti v učenju ljudi vseživljenjskega izobraževanja sploh ne bi bilo. (Krajnc, 2002, str. 3-5) Razvoj izobraževalne poti je povezan s številnimi dejavniki. Na prvem mestu je potrebno omeniti začetno pripravljenost odraslega posameznika za izobraževanje oziroma motivacijo, za katero je najpomembnejši princip prostovoljnosti in integrativnosti. Sa-

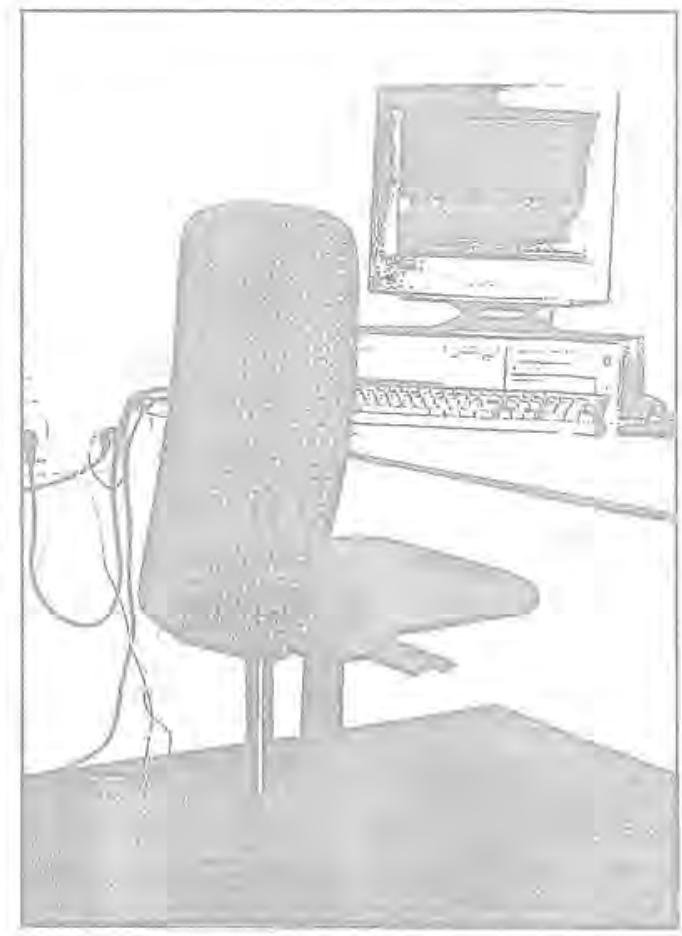

mo zaradi zunanje motivacije odrasli malo časa vztrajajo v izobraževanju - dejstvo je, da so bolj motivirani za učenje stvari, za katere sami ugotovijo, da se jih je potrebno naučiti. M. Knowles pravi, da je potrebno odrasle voditi tako, da sami najdejo vrzeli v svojem znanju in se zaradi nezadovoljstva $\mathrm{z}$ njimi $\mathrm{v}$ njih razvije želja po izboljšanju znanja. Temu priča tudi podatek o uspešnosti odraslih učencev, ki so imeli možnost aktivno posegati $v$ načrtovanje učenja, učitelj pa je služil le kot usmerjevalec in vir znanja. (Knowles, 1981) Vrsta in stopnja motivacije namreč določata temeljnost učenja in kakovost doseženih rezultatov. Od motivacije je odvisno, ali bo šlo za trajno, uporabno, poglobljeno znanje. Pri odraslih se tako pomanjkanje učne motivacije kaže $v$ odporih in pomislekih, ko naj bi se vključili $v$ razne oblike izobraževanja; tisti, ki so imeli slabe izkušnje s šolanjem, pogosto odklanjajo vse, kar "diši" po šolskem izobraževanju, zato pa jih moramo pritegniti z drugačnimi pristopi. (Marentič Požarnik, 2000) O tem govori tudi Knowles, ko pravi, da je 
odrasle treba naučiti novih načinov učenja, zato da v izobraževalni proces vstopijo z močnim egom in dosežejo rezultate, s katerimi so zadovoljni oni sami in učitelj. Potrebno jih je obravnavati kot edinstvene učence. (Knowles, 1981)

Tako bi lahko rekli, da so motivi odraslih za razvoj izobraževalne poti različni; zajemajo pisano množico najrazličnejših spodbud, želja, interesov in potreb; od najbolj praktičnih razlogov do najdolgoročnejših ciljev, ki se že dotikajo samouresničevanja in razvoja osebnosti. Povezani so s celotno človekovo motivacijo, predstavo o sebi in svojih socialnih vlogah ter z dejanskim družbenoekonomskim položajem človeka. Razlike nastajajo s spreminjanjem življenjske situacije, saj se s starostjo in družbenim položajem spreminjajo tudi potrebe, ki jih želi posameznik zadovoljiti.

Navajam nekaj domnev, na podlagi katerih predvidevam, da bi se takšen model, prilagojen okolju, uveljavil tudi v Sloveniji.

- Posamezniki bi bili pripravljeni več vlagati v svoje izobraževanje.

- Podjetja bi bila pripravljena več vlagati v usposabljanje svojih zaposlenih, če bi videla korist.

- Država bi bila pripravljena več vlagati $v$ izobraževanje.

- Izobraževalne možnosti bi bile večje in kakovostnejšse. (Beltram, 2001, str. 38)

Osrednje mesto pri razvoju posameznikove izobraževalne poti pa ima tudi t. i. izobraževalna biografija, ki pomeni nekakšno "snemanje" izobraževanja, spremljanje izobraževalne poti skozi posameznikova življenjska obdobja. Pomeni analizo posameznikovega izobraževanja po formalni in neformalni poti. Posameznik naj sam oceni svoje interese, vrednote, stališča in osebne lastnosti, ugotavlja, katera znanja zna dobro upora-
Uspeh posameznika pri izobraževanju ni pogojen le s subjektivnimi dejavniki, ampak ga v veliki meri pogojujejo tudi širši, družbeni pogoji izobraževanja. Družbene okoliščine morajo zagotoviti sistemsko ureditev, ki spodbuja odrasle $\mathrm{k}$ izobraževanju, dostopnost in pravičnost izobraževanja, ustrezno kakovost življenja, pridobitev višje stopnje formalne izobrazbe. Zaradi tega je potrebno spodbujati razvoj v smeri odpiranja t. i. izobraževalnih računov, kjer gre za nov sistem razvoja izobraževalne poti posameznika. Z njim se odgovornost in materialno breme za izobraževanje posameznika porazdeljujeta med različne socialne partnerje. Individualni izobraževalni načrt ima štiri temelje: prilagodljivost, enotnost, soodgovornost in soudeležbo. Eden izmed temeljnih ciljev individualnega izobraževalnega računa je univerzalen trg izobraževanja, kar pomeni, da lahko vsak učinkovito izrazi svoje potrebe in $\mathrm{k}$ njihovi zadovoljitvi tudi sam, kolikor je mogoče, prispeva.

bljati v življenju in katera še potrebuje. Načrtuje svojo učno pot. Analizira svojo preteklost (kako se je učil), sedanjost (koliko zna in kako se uči) in prihodnost (kako se bo učil in izobraževal). Predvsem so pomembna posameznikova vprašanja: kakšen je moj življenjski načrt, kaj še nisem načrtoval, vendar bi rad dosegel, kaj pričakujem, upam, česa se bojim ... (Govekar-Okoliš, 2000, str. 28)

Vsekakor je za razvoj izobraževalne poti pomembno, da posamezník razmišlja o prihodnosti in se odloča za nove izzive.

\section{OPREDELITEV POJMA SAMOSPOŠTOVANJE}

Rosenberg (Kobal, 2000) opredeli samospoštovanje kot pozitivno ali negativno posameznikovo stališče do samega sebe. Pozitivno stališče ali visoko samospoštovanje pomeni, đa se posameznik sprejema takšnega, kot je, da se ceni, je zadovoljen sam seboj in se čuti vrednega samospoštovanja. In obratno: oseba z negativnim stališčem do sebe ali nizkim samospoštovanjem se ne ceni, svojih lastnosti ne odobrava, njeno mnenje o sebi je. negativno.

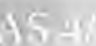




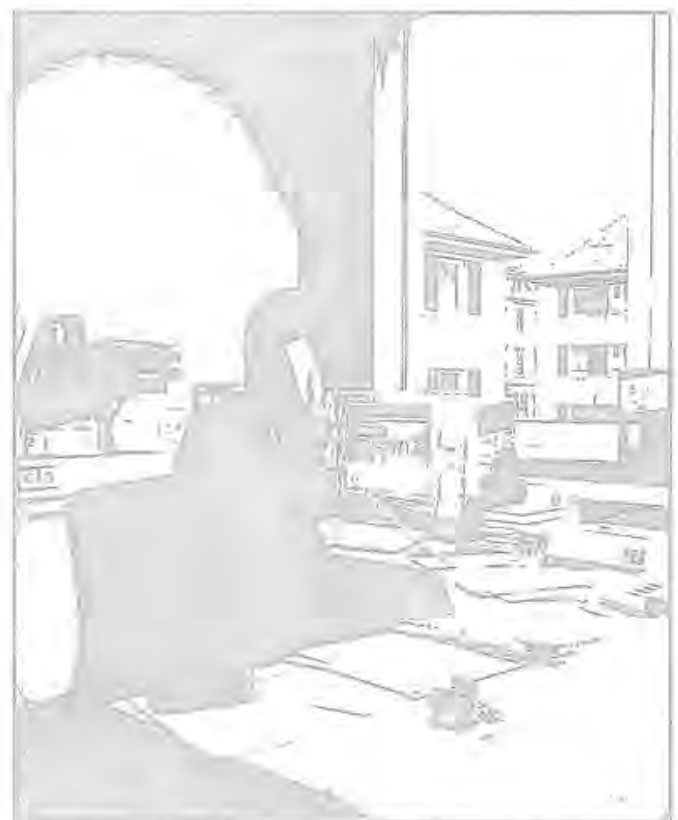

Samospoštovanje je eden izmed dejavnikov, ki pripomore $\mathrm{k}$ temu, da človek sploh lahko obstaja in preživi (being), postaja nekaj, kar še ni bil, in odkriva nove razsežnosti svoje osebnosti (becoming), nekomu pripada in oblikuje svojo osebno identifikacijo ter sistem vrednot (belonging). Predstava o sebi je pri otrocih izrazito dinamičen in fleksibilen pojav, pri odraslem pa se oblikuje pod vplivom dveh komponent:

- dosežkov, pridobljenih z lastnim delom in ustvarjalnostjo,

- na osnovi odnosov z drugimi ljudmi oziroma svoje zrcalne slike, ki se odraža v stališčih in mnenjih drugih (Krajnc, 1979 . str. 42).

Zanimivo je, v kolikšni meri so prav medsebojni odnosi tisti, ki pri človeku zelo hitro porušijo predstavo o sebi. Vendar je potrebno omeniti tudi drugo dimenzijo, ki pomaga vzdrževati ravnotežje pri predstavi o sebi: lastne reakcije na dosežene rezultate.

Na samospoštovanje vplivajo določene zakonitosti $v$ procesu osebnostnega razvoja. Tako
Freudovo pojmovanje oblikovanja osebnosti skuša celotno človekovo vedenje, tudi v odrasli dobi, razložiti z izkušnjami in strukturo osebnosti, ki jo je posameznik pridobil v zgodnjem otroštvu. Kot da se Freud odpoveduje vsem izkustvom in doživljajem $v$ odraslosti. Nikjer v literaturi ni zaslediti, da bi Freud omenjal samospoštovanje kot dimenzijo, ki bi se pojavila na relaciji id, ego in superego. V svoji teoriji pušča zelo malo prostora za osebnostni razvoj odraslih, saj meni, da je psihološki razvoj človeka določen z njegovo biološko naravo in fizičnim zorenjem, ki pa se konča y obdobju adolescence. Kasnejše vedenje odraslih pojmuje kot zrcalno sliko zadovoljenih oziroma nezadovoljenih motivov iz otroštva. Glede na Freuda pomeni velik premik Eriksonova teorija stopenjskega razvoja odraslih. Glavna značilnost stopenjskega razvoja je sukcesivnost vsakega obdobja, ki ni le kakovostno drugačno, ampak se tudi vsebinsko razlikuje od predhodne stopnje oziroma obdobja. Ločnica med posameznimi obdobji je kriza; posamezne stopnje so med seboj povezane glede na način razreševanja kriz. $\mathrm{Z}$ vidika teme, $\mathrm{ki}$ jo opisujem, je potrebno opozoriti na peto stopnjo $\mathrm{v}$ razvoju, ki govori o konfliktnem razmerju med identiteto in nejasno predstavo o sebi. Erikson meni, da je to obdobje, v katerem najintenzivneje iščemo svojo identiteto, predstavo o sebi. Razvoju identitete daje mesto na vseh osmih stopnjah, po načelu zaporednosti - $\mathrm{z}$ vsako stopnjo višje je identiteta konstantnejša.

Identiteta je nadreden pojem samospoštovanju, vsebuje organizirano strukturo vrednot in prepričanj o nas samih. Govorimo o dveh pojmih: o socialni in osebni identiteti. (Brečko, 1998, str. 55) Potrebno je opozoriti tudi na povezovanje znanja in spremembo identitete. Vemo, da se posameznik identificiras svojimi izkušnjami, zato se vedno znova čuti ogroženega, če novih znanj ne more povezati s prejšnjimi izkušnjami. 
Če sem torej napisala, da je samospoštovanje eden ključnih dejavnikov oblikovanja posameznikove identitete, potem lahko sklepam, da je samospoštovanje dejavnik, ki se zvišuje $s$ količino znanja in stopnjo izobrazbe, ki ju posameznik ima. Z izobraževanjem namreč človek daje svoji osebnosti nove razsežnosti in sorazmerno s tem se zvišuje tudi njegovo samospoštovanje.

\section{SAMOSPOŠTOVANIE IN RAZVIJANJE IZOBRAŽEVALNE POTI}

Ugotavljala sem, kakšno samospoštovanje imajo posamezniki $\mathrm{z}$ različnimi stopnjami končane izobrazbe. V vzorcu raziskave je bilo zajetih sto posameznikov, od tega jih je dvajset imelo magistrski naziv, dvajset končano srednjo šolo, dvajset končano poklicno šolo, dvajset končano osnovno in dvajset nedokončano osnovno šolo. Bili so različne starosti in so se razlikovali po spolu. Vzorec sem naključno izbrala. Podatke sem zbirala s pomočjo lestvice samospoštovanja (krajša verzija) avtorice Tanje Lamovec. Končni rezultat na lestvici samospoštovanja sem dobila tako, da sem seštela dosežene točke. Visoko število točk pomeni visoko globalno samospoštovanje.

Odkrivala sem vzroke za prekinitev izobraževalne poti in vzroke za njeno nadaljevanje. Akademska samopodoba $\mathrm{v}$ precejšnji meri vpliva na celoten koncept samospoštovanja, kar pomeni, da je pričakovati soodvisnost med spremenljivkami. Zlasti ob predpostavki, da izobraževanje povzroči rekonstrukcijo posameznikove identitete, lahko predpostavljamo, da je dosežena stopnja izobrazbe eden izmed dejavnikov, ki vplivajo na posameznikovo samospoštovanje, in obratno. Pri načrtovanju in razvoju osebne izobraževalne poti je pomembna zavest o sebi, zavedati se je treba svojega jaza ali sebstva, ker posamezniku omogoča, da se prepozna kot indivuduum nasproti različnim socialnim oko-

ljem. Pomembno je, da celotna shema jaza vsebuje vse tisto, kar posameznik sprejme kot oznako sebe. Slednje namreč pri razvoju izobraževalne poti omogoča realno oceno izobraževanja, učenja, znanja in osebnostnih lastnosti ter sposobnosti.

Namen članka je torej prikazati, da $v$ obdobju odraslosti posameznik prav tako teži $\mathrm{k}$ oblikovanju in preoblikovanju svoje identitete, k oblikovanju

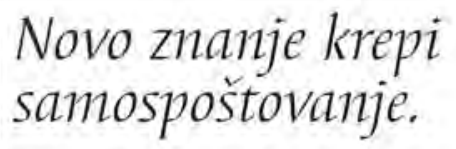

samega sebe. $Z$ nenehnim izobraževanjem in učenjem pridobiva samospoštovanje nove razsežnosti - višja ko je stopnja izobrazbe, ki jo je posameznik dosegel, širše dimenzije $v$ zaznavanju samega sebe ima.

$\mathrm{V}$ grafu 1 je prikazana primerjava aritmetiěnih sredin na lestvici samospoštovanja. Povprečna ocena rezultatov na lestvici samospoštovanja pri posameznikih z nedokončano osnovno šolo znaša 64,6 . Eden izmed anketirancev je dosegel manj kot 49 točk, kar predstavlja 5 odstotkov. 17 anketirancev ali 85 odstotkov jih je doseglo od 50 do 70 točk, 2 ali 10 odstotkov od 71 do 95 točk. V primerjavi $z$ ostalimi $v$ vzorcu so anketiranci $\mathrm{Z}$ nedokončano osnovno šolo pogosteje navajali odgovore "ne vem", kar je pripomoglo k manjšemu številu točk. Povprečna ocena rezultatov na lestvici samospoštovanja pri po-

Dejstvo je, da smo s pozitivnejšo predstavo o sebi ponavadi v življenju, učenju in izobraževanju uspešnejšsi. Kadar se bolj zavedamo sami sebe, znamo bolje razmišljati o sebi, svojih stališčih, pričakovanjih in laže najdemo in odpravimo vzroke nezadovoljstva. Pomembno je, da se posameznikovo samospoštovanje nadgrajuje vse življenje, tako kot se kopiči bogastvo izkušenj. Vseživljenjski razvoj samospoštovanja in kopičenje izkušenj potekata vzporedno - sta pravzaprav osnova za razvoj izobraževalne poti posameznika. 
sameznikih s končano osnovno šolo znaša 70,3 , kar je bistveno več kot pri anketirancih z nedokončano osnovno šolo. 12 ali 60 odstotkov jih je doseglo od 50 do 70 točk, v primerjavi $\mathrm{z}$ anketiranci, $\mathrm{ki}$

\section{Z izobraževanjem dodajamo svoji osebnosti nove razsežnosti.}

imajo nedokončano osnovno šolo, pa je bilo bistveno več takšnih, ki so imeli 71 točk ali več - kar 40 odstotkov. Povprečna ocena rezultatov na lestvici samospoštovanja pri posameznikih s končano poklicno izobrazbo je 69,6 , kar je za 0,7 točke manj kot pri anketirancih s končano osnovno šolo. 9 ali 45 odstotkov anketirancev je doseglo od 50 do 70 točk, 11 anketirancev ali 55 odstotkov pa je doseglo več kot 71 točk.

Povprečna ocena rezultatov na lestvici samospoštovanja pri posameznikih s končano srednjo šolo je 72,3, kar je za 2,7 točke več kot pri posameznikih $s$ končano poklicno šolo. Sedem ali 35 odstotkov vprašanih je imelo od 50 do 70 točk, trinajst ali 65 odstotkov pa od 71 do 95 točk. Povprečna ocena rezultatov na lestvici samospoštovanja pri posameznikih s končanim magisterijem je 78,8 , kar je najvišje v primerjavi $\mathrm{z}$ ostalimi rezultati. Le 2 posameznika ali 10 odstotkov vseh vprašanih sta imela od 50 do 70 točk, ostali, torej 18 posameznikov ali 90 odstotkov vprašanih, pa je doseglo od 71 do 95 točk.

Iz grafa 1 so nazorno vidne razlike med povprečnimi vrednostmi posameznih skupin. Posamezniki z višjo stopnjo končane izobrazbe so imeli višje rezultate na področju socialnega, telesnega in emocionalnega jaza, ki ga je merila lestvica samospoštovanja.

Višja kot je bila stopnja izobrazbe posameznika, več točk na lestvici je dosegel. Eden od možnih odgovorov, s katerim lahko utemeljimo odvisnost, je tudi izgradnja identitete odraslega. V procesu osebnega razvoja namreč človek vse življenje teži k oblikovanju in preoblikovanju identitete ali k oblikovanju samega sebe in razvijanju občutka lastne vrednosti. Z izobraževanjem daje svoji osebnosti nove razsežnosti, prihaja do rekonstrukcije identitete. Vsaka nova situacija v življenju odraslega namreč povzroči zmedo identitete - ob vstopu v novo socialno skupino

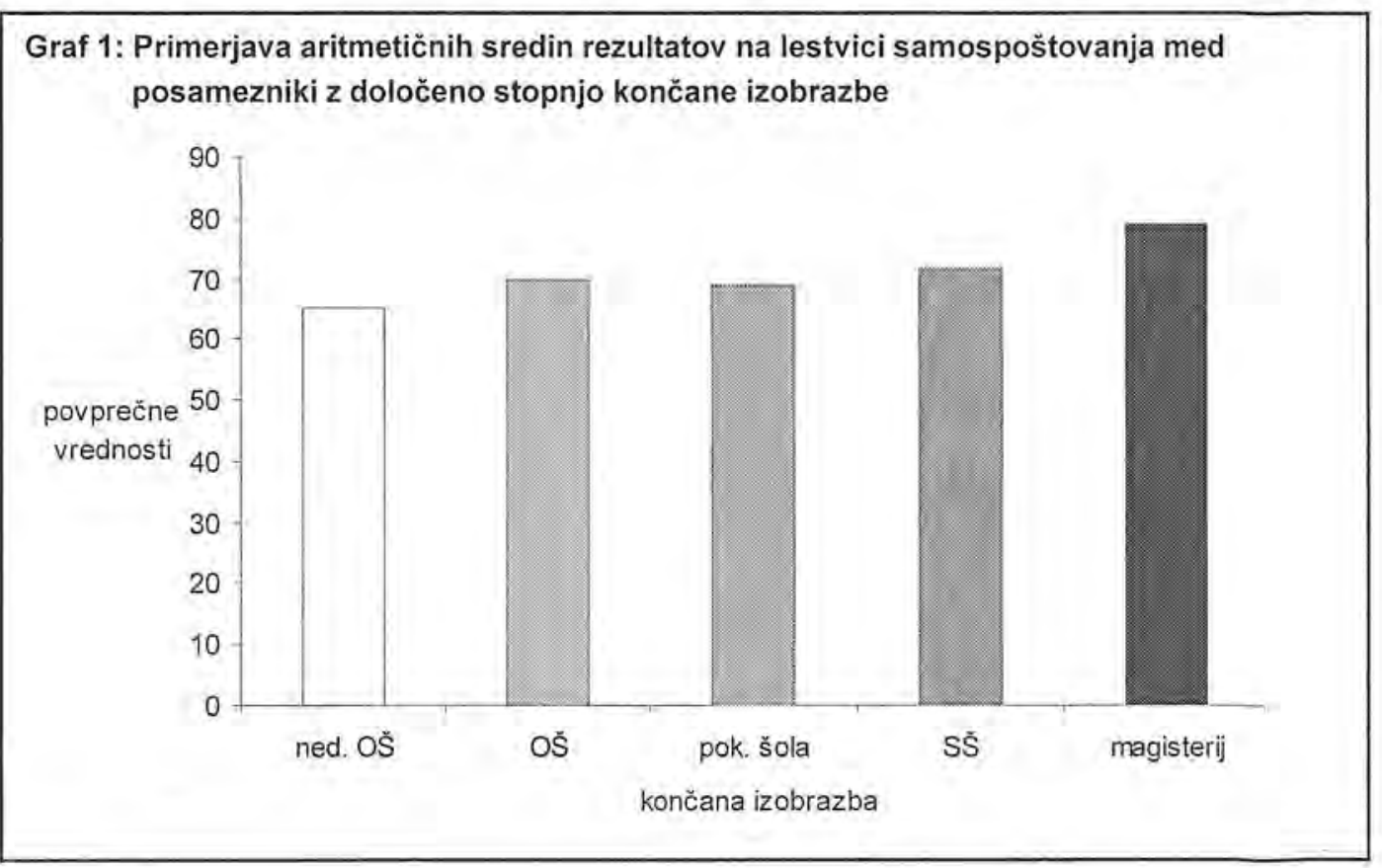


skuša posameznik ohraniti obstoječo identiteto, vendar to ni mogoče, ker se mora v vsaki novi situaciji prilagajati novim zakonitostim procesov skupinske dinamike. (Brečko, 1998)

Posameznik, ki se nenehno uči, posameznik, ki nenehno vstopa $\mathrm{v}$ nove komunikacijske odnose, pogosto vzpostavlja novo identiteto in s tem tako osebnostno kot poklicno raste.

Ker pa sem iskala tudi morebitno odvisnost med samospoštovanjem in graditvijo izobraževalne poti, v nadaljevanju predstavljam vzroke za prekinitev izobraževalne poti. Ugotovila sem, da obstaja odvisnost med vzrokom za prekinitev izobraževanja in stopnjo končane izobrazbe. Vzroki, zakaj so posamezniki prekinili svojo izobraževalno pot, se med posameznimi vzorci, zajetimi $\mathrm{v}$ raziskavo, razlikujejo. Morda bi lahko namesto vzrokov za prekinitev izobraževalne poti uporabljala izraz ovire za nadaljevanje izobraževanja. Le-te delimo $v$ tri skupine: situacijske, institucionalne in dispozicijske. V nadaljevanju skušam posamezne ovire interpretirati $\mathrm{v}$ povezavi s končano stopnjo izobrazbe.

V vzorcu so bili zajeti posamezniki različne starosti, zato lahko z veliko stopnjo gotovosti trdimo, da so rezultati realni. Leta nazaj namreč šolski sistem ni ponujal tako široke palete izobrazbenih možnosti in je velik odstotek posameznih generacij že v osnovni šoli izstopil iz izobraževanja. Tako bi lahko vzroke za prekinitev šolanja pri posameznikih $\mathrm{z}$ nedokončano osnovno šolo iskali predvsem v dispozicijskih ovirah, ki se povezujejo s psihosocialnimi značilnostmi posameznika.

Posamezniki z nedokončano osnovno šolo so kot poglavitni vzrok za prekinitev šolanja navajali neuspeh $\mathrm{v}$ šoli - kar 55 odstotkov ali 11 posameznikov, 5 ali 25 odstotkov jih je prekinilo šolanje zaradi slabega finančnega stanja družine, 4 ali 20 odstotkov pa zato, ker so dobili službo.

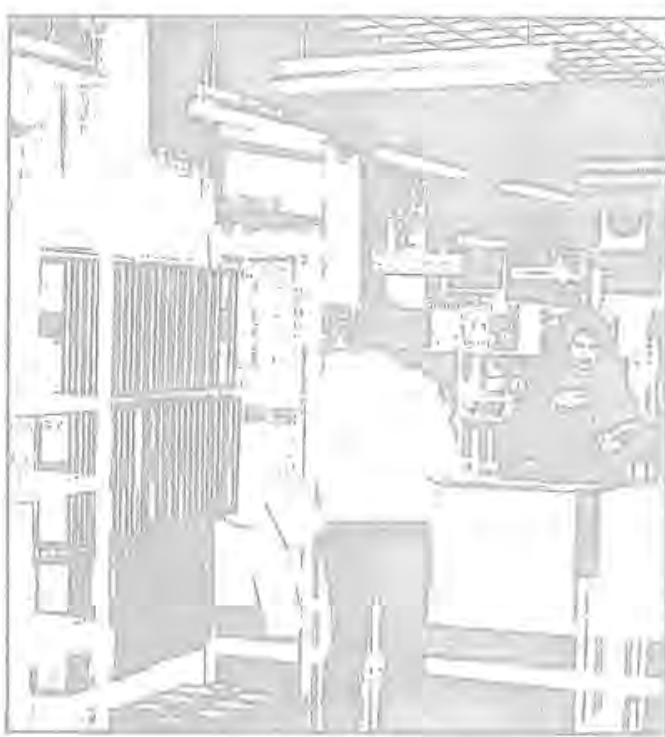

Ne gre zanemariti tudi situacijskih ovir, ki se $v$ naši raziskavi izražajo predvsem $v$ slabem finančnem stanju.

Posamezniki s končano osnovno šolo so kot vzroke za prekinitev šolanja navajali neuspeh v šoli (7 posameznikov ali 35 odstotkov), slabo finančno stanje družine (5 posameznikov ali 25 odstotkov), mnenje, da višje izobrazbe ne potrebujejo ( 5 posameznikov ali 25 odstotkov), in dejstvo, da so si ustvarili družino (3 posamezniki ali 15 odstotkov). Vidimo, da je tudi tu narava ovir enaka, čeprav se že razširi tudi na oviro, kot je ustvarjanje družine. Iz analize rezultatov je razvidno, da so te vrste oviro navedle ženske. Velik del vzorca s končano osnovno šolo izhaja s podeželja, kjer je bila nekoč razvita tekstilna industrija in zato vzrok "višje izobrazbe ne rabim" ni presenetljiv. Pred leti je bila pot do zaposlitve lažja kot sedaj in delavci s končano osnovno šolo so se zaposlovali predvsem $v$ tekstilni industriji.

Zanimivi so tudi vzroki za prenehanje izobraževanja pri posameznikih s končano poklicno izobrazbo. Glede na to, da so se usposabljali v procesu izobraževanja za določen poklic, je 12 odgovorov ali 60 odstotkov odgovorov "višje izobrazbe ne potrebujem" 
realnih. Tudi tu sta prisotna odgovora neuspeh v šoli ( 3 ali 15 odstotkov) in slabo finančno stanje družine ( 3 ali 15 odstotkov), 2 ali 10 odstotkov pa sta dobila službo in zato nista nadaljevala $\mathrm{z}$ izobraževanjem.

Povsem drugačni vzroki za prekinitev šolanja se pojavijo pri populaciji s končano srednjo šolo. Vzrokov je več, izstopa pa ustvarjanje družine - pri 5 ženskah in 3 moških, kar znaša 40 odstotkov. Sledijo vzroki z enakimi deleži 4 ali 20 odstotkov: neuspeh v šoli, slabo finančno stanje družine in zaposlitev.

Med tistimi, ki so $\mathrm{z}$ magistrskim nazivom prekinili izobraževanje, jih je 8 ali 40 odstotkov takšnih, ki so mnenja, da višje izobrazbe ne potrebujejo, 2 ali 10 odstotkov si jih je ustvarilo družino in jim to predstavlja oviro za izobraževanje, 7 jih sploh ni prekinilo izobraževanja, 3 ali 15 odstotkom pa obveznosti v službi ne dovoljujejo nadaljnjega izobraževanja. Iz analize odgovorov je razvidno, da so najpomembnejše ovire, ki so odraslim preprečevale udeležbo $v$ nadaljnjem izobraževanju in s tem graditev svoje izobraževalne poti, dispozicijske in situacijske, manj institucionalne. Kot pa je jasno iz analize, se ovire razlikujejo glede na stopnjo izobrazbe posameznikov.

Zanimivo bi bilo raziskati ovire po spolu izstopile bi verjetno družinske obveznosti, ki po nekaterih ugotovitvah prejšnjih raziskav preprečujejo uresničitev motivov za izobraževanje skoraj petini žensk. Pri moških je ta delež ovire zanemarljiv. (Radovan, 2002, str. 27)

Glede na to, da 55 posameznikov, zajetih v vzorec, razvija svojo izobraževalno pot, kar pomeni, da se izobražujejo za pridobitev višje izobrazbe, so v grafu 3 predstavljeni vzroki za nadaljevanje šolanja posameznikov.

Vzroki za nadaljevanje izobraževalne poti, analizirani ne glede na stopnjo izobrazbe, so naslednji: imeti višjo stopnjo izobrazbe (19 odgovorov ali 35 odstotkov), z izobrazbo si zagotoviti boljše finančno stanje (14 odgovorov ali 25 odstotkov), z izobraževanjem si zagotoviti večjo možnost napredovanja $\mathrm{v}$ službi ( 11 odgovorov ali 20 odstotkov), nada-

Graf 2: Vzroki za nadaljevanje šolanja ne glede na stopnjo dosežene izobrazbe

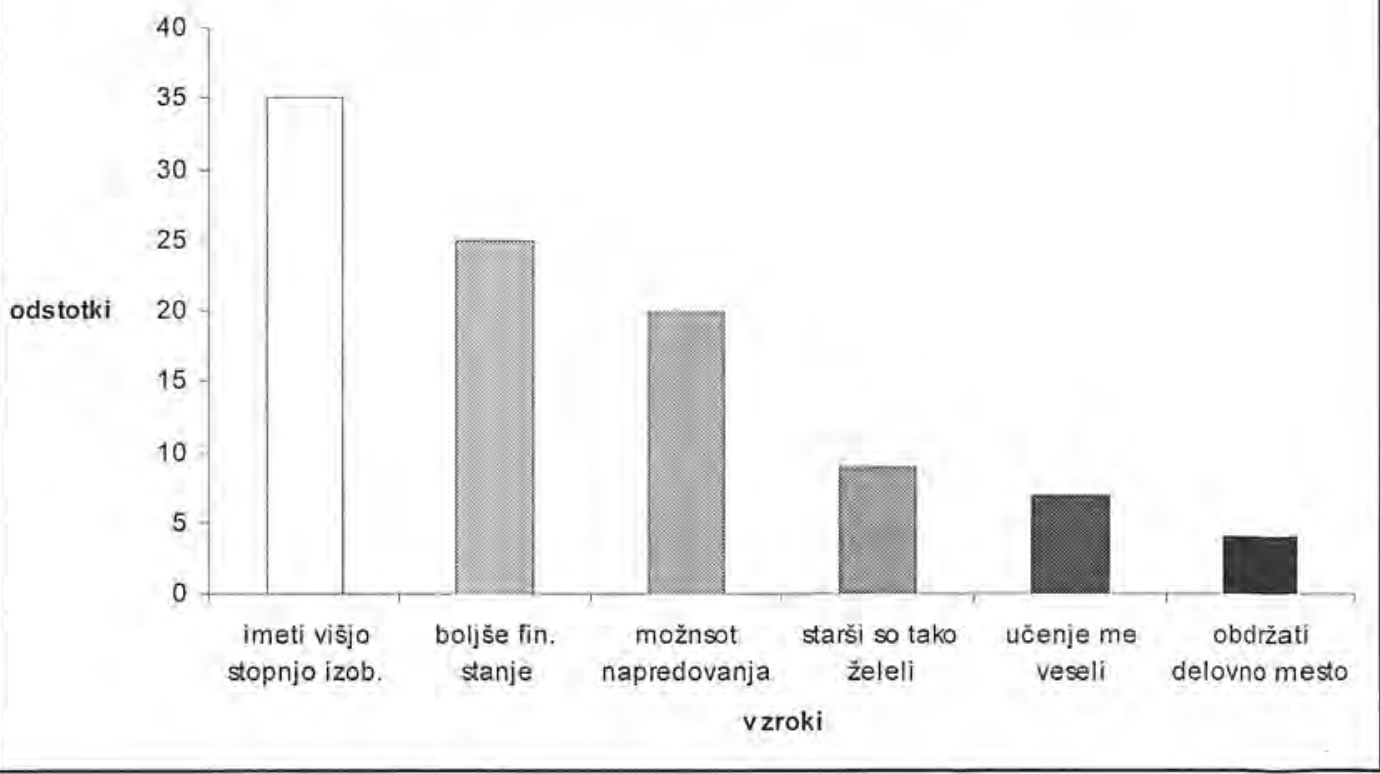


ljevati z izobraževanjem na željo staršev (5 odgovorov ali 9 odstotkov), nadaljevati zaradi veselja do učenja (4 odgovori ali 7 odstotkov), obdržati trenutno delovno mesto ( 2 odgovora ali 4 odstotki). Vseh posameznikov, ki so zajeti $\mathrm{v}$ vzorec in nadaljujejo $\mathrm{z}$ izobraževanjem, je 55; od tega jih ima 8 nedokončano osnovno šolo in se izobražujejo na Ljudski univerzi v Žalcu v programu za pridobitev osnovnošolske izobrazbe, 11 jih ima končano osnovno šolo in se izobražujejo v programu trgovec, 12 jih ima poklicno izobrazbo in nadaljujejo izobraževanje po programih ekonomsko-komercialni tehnik, vrtnarski tehnik, gostinski tehnik. 14 posameznikov s končano srednjo šolo se izobražuje $v$ programih vzgojitelj predšolskih otrok, zdravstvena nega in višji upravni delavec, 10 magistrov ali 50 odstotkov pa jih nadaljuje $\mathrm{z}$ doktorskim študijem. Seveda se odgovori razlikujejo glede na stopnjo izobrazbe, zato jih $v$ nadaljevanju podrobneje analiziram.

Posamezniki z nedokončano osnovno šolo kot vzrok za nadaljevanje izobraževanja navajajo boljše finančno stanje (60\%), željo staršev, da nadaljujejo z izobraževanjem (20\%), in željo imeti višjo stopnjo izobrazbe (20\%).

Posamezniki s končano OŠ navajajo: starši so tako želeli (40\%), želim imeti višjo stopnjo izobrazbe $(35 \%)$ in boljše finančno stanje (20\%), Glede na to, da je bil vzorec starostno heterogen, so vzpodbude staršev za šolanje prisotne pri mlajših posameznikih.

Posamezniki s končano poklicno šolo navajajo takole: starši so tako želeli in boljše finančno stanje $\mathrm{v} 20$ odstotkih, možnost napredovanja v 18 odstotkih in želja imeti višjo stopnjo izobrazbe $v 15$ odstotkih.

Posamezniki s končano srednjo šolo navajajo: 25 odstotkov imeti višjo stopnjo izobrazbe, 28 odstotkov višja možnost napredovanja, 8 odstotkov boljše finančno stanje.

Posamezniki s končanim magisterijem so se za doktorski študij odločili, ker jih učenje veseli in želijo obdržati delovno mesto (znotraj cele populacije sta to odgovora, ki ju ni izbral nihče drug $\mathrm{z}$ drugačno stopnjo izobrazbe). Vsekakor pa se je moja hipoteza, da se posamezniki za nadaljevanje šolanja odločajo predvsem zaradi tega, ker se radi učijo in ker so notranje motivirani, potrdila le pri posameznikih $\mathrm{z}$ magistrskim nazivom, drugje pa jo moram zavrniti,

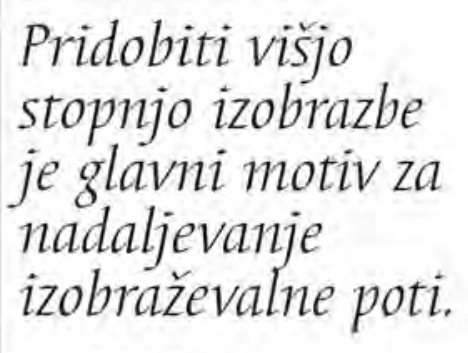

Iz analize je razvidno, kako se vzroki razlikujejo; o njih bi lahko razpravljali tudi v zvezi $\mathrm{z}$ motivacijo - ta glede na stopnje izobraževanja $z$ nižje na višjo prehaja iz tipiěno zunanje $v$ notranjo in je pri magisteriju skoraj povsem notranja.

\section{ZAKLJUČEK}

Glede na to, da sem v prvem delu prispevka podala teoretična izhodišča vseživljenjskega učenja, razvoja izobraževalne poti in samospoštovanja, sem v raziskovalnem delu želela poiskati povezave med njimi.

Rezultati, ki so jih dosegli posamezniki na lestvici samospoštovanja, so potrdili moja predvidevanja. Ugotovila sem, da imajo posamezniki z višjo stopnjo izobrazbe višje samospoštovanje - le skupina s končano poklicno šolo je imela za malenkost nižji povprečni

Na nadaljevanje izobraževalne poti posameznika $v$ veliki meri vplivajo stereotipne predstave o izobraževanju. Ti stereotipi, ki izhajajo predvsem iz negativnih ali pozitivnih izkušenj v rednem izobraževanju, se skupaj s socialno-ekonomsko situacijo, $\checkmark$ kateri se nahaja posameznik, "oblikujejo" v stališča, pričakovanja in percepcije posameznika v zvezi z izobraževanjem, ki zaviralno ali pozitivno vplivajo na motivacijo za učenje. 
rezultat kot skupina s končano osnovno šolo. Menim, da vzroke za potrditev predvidevanj lahko iščemo v več dejavnikih samospoštovanja; splošno samospoštovanje je namreč sestavljeno iz individualne in medosebne samopodobe. Individualno samopodobo tvorita samopodoba na podlagi uspešnosti (izobraževanje, delo, materialni uspeh) in telesna samopodoba (sposobnosti, videz). Medoseb-
Ljudje z višjo stopnjo izobrazbe imajo višjo raven samospostovanja. na samopodoba je sestavljena iz socialne in družinske samopodobe, ki ju tvorijo odnosi in odgovornosti. Nekatere od naštetih komponent so močno vplivale na končne rezultate samospoštovanja.
Pri primerjavi razlik med aritmetičnimi sredinami posameznih skupin sem ugotovila, da se razlike zvišujejo glede na razpon med stopnjami izobrazbe. Tako se je najvišja razlika v povprečnih rezultatih merjenja samospoštovanja pojavila med najnižjo stopnjo izobrazbe (nedokončana OŠ) in najvišjo (končan magisterij). Rezultat lahko utemeljimo s tem, da se vzorca verjetno ne razlikujeta le glede na vsa podpodročja samospoštovanja, ampak v veliki meri tudi glede na odnos, ki ga imajo posamezniki v vzorcih do sebe in svoje samoaktualizacije, Posamezniki z nedokončano osnovno šolo nimajo znanj o tem, kako spoznavati sebe, se uresničevati, težko definirajo svoje pozitivne lastnosti, imajo težave pri reflektiranju svojih dejavnosti. Posledica so tudi pogosti odgovori "ne vem" na vprašalniku. Tudi metodološki preizkus neodvisnosti je pokazal stopnjo odvisnosti med končano izobrazbo in rezultatom na lestvici samopoštovanja ter potrdil moja predvidevanja.

Vzroki, zaradi katerih so posamezniki prekinili izobraževanje, se prav tako razlikujejo glede na stopnjo končane izobrazbe. Kot najpomembnejši vzroki so se pojavljali: mnenje, da posameznik višje izobrazbe ne potrebuje, neuspeh v šoli, slabo finančno stanje družine. Vzroke sem umestila med situacijske, institucionalne in dispozicijske ovire in ugotovila, da je najmanj institucionalnih. Posamezniki so navajali tudi finančne vzroke prekinitve šolanja. Menim, da je ravno za finančne ovire značilno, da s stopnjo izobrazbe in zahtevnostjo delovnega mesta njihov delež pada, kar potrjujejo tudi podatki iz raziskave. Največji odstotek vzrokov za prekinitev izobraževanja zaradi finančnih težav je bil pri populaciji z nedokončano in končano osnovno šolo. Sicer pa so vzroki specifični glede na stopnjo izobrazbe - ni enotnega vzroka, ki bi se pojavljal pri vseh skupinah.

Rezultati kažejo tudi na to, kako se spreminja motivacija oziroma motiv za izobraževanje glede na stopnjo motivacije - prehaja iz zunanje v notranjo. Spoznanja v raziskovalnem delu so osmislila teoretična izhodišča, pri čemer je verjetno najpomembnejše spoznanje naslednje: samospoštovanje, ki sem ga merila z lestvico, je samo eden izmed dejavnikov, ki vplivajo na izobraževalno pot posameznika. Ob predpostavki, da je najpomembnejše merilo osebnega izobraževanja jasen cilj, je človek z jasno uspešno identifikacijo lahko uspešnejši. Zato se strinjam, da je treba stereotipe presegati, omogočiti dostopnost informacij, seznanjati z njimi tudi

Najpogostejši vzroki za nadaljevanje izobraževalne poti posameznika so: želja po višji stopnji izobrazbe, izboljšati finančno stanje, imeti večjo možnost napredovanja, želja staršev, veselje do učenja in želja obdržatí delovno mesto. V ospredju je želja po izboljšanju finančnega stanja, ki v procesu izobraževanja deluje kot učinkovito motivacijsko sredstvo. Pri posameznikih, ki nadaljujejo $z$ doktorskim študijem, je vzrok za nadaljevanje študija veselje do učenja, ki je seveda $v$ funkciji notranje motivacije. 
starejše z nizko izobrazbo in nizkim socialnim statusom. Le tako bomo lahko rekli, da tudi pri nas sledimo trendom, ki jih poudarja teorija človeškega kapitala: ceni tako znanje, izkušnje kot tudi spretnosti.

\section{LITERATURA}

Beltrăm, P. (2001). Individualni izobraževalni račun. Andragoška spoznanja, št, 2, str. 32-40,

Brečko, D. (1995). Osebnostni razvoj in učenje odraslih. Andragoška spoznanja, št. 1-2, str. 10-13.

Brečko, D. (1998). Kako se odrasli spreminjamo? Didakta.

Brečko, D. (1999a). Metode izobraževanja odraslih. Andragoška spoznanja, št. 1, str. 64-68.

Brečko, D. (1999b). Vseživljenjski razvoj osebnosti (1. del). Andragoška spoznanja, št. 2, str: 6-16.

Brečko, D. (1999c). Vseživljenjski razvoj osebnosti (2. del). Andragoška spoznanja, št. 3, str. 27-40.

Brečko, D. (2000a). Predstava o sebi in načrtovanje kariere. Andragoška spoznanja, št. 2, str. 41-53.

Brecko, D. (2000b). lzobraževanje in razvoj kariere. Andragoška spoznanja, §t. 3, str. 28-36.

Cross, K. P. Adults as Learners. San Francisco: Josseybass, http://tip.psyhology.org/cross.html.

Dobnik, N. (2000), Osebni izobraževalni načrt. Andragoška spoznanja, št. 3, str, 60-67.

Dryden, G, Vos, J. (2001). Revolucija učenja, Ljubljana: Educy.

Drucker, P. (2001). The next society. The Economist, novenber.

Edwards, R. (1997). Changing places? Flexibity, Lifelong learning and Learning Society. London in New York: Routledge.

Govekar-Okoliš, M. (2000). Izobraževalna biografija. Andragoška spoznanja, št. 4, str. 27-43.

Vseživljenjsko izobraževanje in vseživljenjsko učenje (1998), Jelenc, Z. (ur,), Ljubljana: Andragoški center RS.

Knowles, M. (1980). The modern practice of adult education. Cambridge.

Kobal, D. (2000), Temeljni vidiki samopodobe. Ljubljana: Pedagoški inštitut.

Krajne, A. (1982). Motivacija za izobraževanje. Ljubljana: Delavska enotnost.

Krajnc, A. (1995a). Futurološki pogled na šolo in permanentno izobraževanje. Sodobna pedagogika, I. $46 / 112$, st. 5-6, str. 225-232.
Krajnc, A. (1995b), Futurološki pogled na šolo in permanentno izobraževanje. Sodobna pedagogika, št. 5-6, str. 225-233.

Krajnc, A. (1996). Kakšno znanje potrebuje sodobni človek. Andragoška spoznanja, št. 3, str. 5-10.

Krajuc, A. (2000), Kdo odloča o tem, česa se bodo ljudje učili? Andragoška spoznanja, št. 2, str. 34-43.

Krajnc, A. (2002). Učna okolja. Andragoška spoznanja, st. I, str. 3-5.

Lamovec, T. (1994). Psihodiagnostika osebnosti 2. Ljubljana: FF, str. 84-85.

Radovan, M. (2002). Ovire odraslih pri vključevanju v izobraževanje. Adragoška spoznanja, št. 1, str. 24-30. 